\title{
ANALISIS PENGARUH CORPORATE SOCIAL RESPONSIBILITY DAN KEBIJAKAN DIVIDEN TERHADAP NILAI PERUSAHAAN DENGAN PROFITABILITAS SEBAGAI VARIABEL PEMODERASI STUDI PADA INDUSTRI PERBANKAN
}

\author{
Riana Wulandari ${ }^{*}$, Sigit Wibowo DN1 ${ }^{1}$, Ary Yunanto ${ }^{1}$ \\ ${ }^{1}$ Jurusan Manajemen, Fakultas Ekonomi dan Bisnis, Universitas Jenderal Soedirman, Jawa Tengah, \\ Indonesia \\ ${ }^{*}$ Email corresponding author: riana.wulandari97@gmail.com
}

\begin{abstract}
Abstrak
Penelitian ini bertujuan untuk menganalisis pengaruh corporate social responsibility (CSRDI) dan kebijakan dividen (DPR) terhadap nilai perusahaan (PBV) yang dimoderasi dengan profitabilitas (ROA) pada industri perbankan yang terdaftar di Bursa Efek Indonesia periode 2013 - 2017. Populasi dalam sampel ini adalah sebanyak 43 perbankan. Sampel yang digunakan dalam penelitian ini sebanyak 12 perbankan. Sampel diambil dengan metode purposive sampling. Data dalam penelitian ini dianalisis dengan regresi data panel dan regresi moderasi. Hasil penelitian menunjukkan bahwa corporate social responsibility (CSRDI) tidak berpengaruh terhadap nilai perusahaan (PBV), kebijakan dividen (DPR) berpengaruh positif dan signifikan terhadap nilai perusahaan (PBV), profitabilitas (ROA) tidak mampu memoderasi pengaruh corporate social responsibility (CSRDI) terhadap nilai perusahaan (PBV) dan profitabilitas (ROA) mampu memoderasi pengaruh kebijakan dividen (DPR) terhadap nilai perusahaan (PBV).
\end{abstract}

Kata Kunci: corporate social responsibility disclosure index (CSRDI), dividend payout ratio (DPR), return on assets (ROA) dan price to book value (PBV)

\begin{abstract}
This study aims to analyze the influence of corporate social responsibility (CSRDI) and dividend policy (DPR) on firm value (PBV) which is moderated with profitability (ROA) in the banking industry listed on the Indonesia Stock Exchange for the period of 2013 - 2017. The population in this study was 43 banks. The sample used in this study were 12 banks. Sample were taken by purposive sampling method. Data in this study were analyzed with panel data regression and moderation regression. The result showed that corporate social responsibility (CSRDI) has no effect on firm value ( $P B V)$, dividend policy (DPR) has positive and significant on the firm value $(P B V)$, profitability (ROA) was unable to moderate the effect of corporate social responsibility (CSRDI) on firm value and profitability (ROA) are able to moderate the effect of dividend policy $(D P R)$ on firm value $(P B V)$.
\end{abstract}

Keywords: Corporate Social Responsibility Disclosure Index (CSRDI), Dividend Payout Ratio (DPR), Return On Assets (ROA) dan Price To Book Value (PBV).

\section{PENDAHULUAN}

Didirikannya suatu perusahaan pasti mempunyai tujuan yang akan dicapai. Menurut Harjito dan Martono (2010:2) tujuan perusahaan adalah untuk mencapai laba yang maksimal, memakmurkan pemilik perusahaan atau para pemegang saham dan memaksimalkan nilai perusahaan. Untuk mencapai tujuan tersebut perusahaan harus melakukan kegiatannya secara efektif dan efisien. Efektif dalam hal mencapai tujuan yang ingin dicapai dan efisien berkaitan dengan biaya yang dikeluarkan untuk mencapai tujuan tersebut. Nilai perusahaan dapat terlihat dari harga saham perusahaan. Nilai perusahaan yang tinggi berdampak pada kemakmuran pemegang sahamnya sehingga dengan jaminan kesejahteraan tersebut para investor pun tidak akan ragu untuk menanamkan modalnya. Nilai 
perusahaan sangatlah penting karena menggambarkan kinerja perusahaan yang dapat mempengaruhi persepsi para investor. Dalam penelitian ini nilai perusahaan diukur dengan price to book value (PBV).

Untuk mengukur tingkat keuntungan suatu perusahaan digunakan suatu rasio yaitu rasio profitabilitas, salah satunya dapat diukur dengan return on assets (ROA). Dengan semakin meningkatnya pertumbuhan profitabilitas perusahaan maka akan semakin baik pula prospek perusahaan dimasa yang akan datang. Dalam hal ini salah satunya pada industri perbankan yang sahamnya diminati para investor untuk berinvestasi, karena perbankan berpotensi menghasilkan laba yang cukup bagus dalam pertumbuhan ekonomi di Indonesia.

Berikut adalah data rata-rata harga saham, return on assets (ROA) dan price to book value (PBV) industri perbankan. Data tersebut dihitung berdasarkan pada sampel industri perbankan yang terdaftar di Bursa Efek Indonesia periode 2013 - 2017.

Tabel 1. Rata-Rata Harga Saham, ROA dan PBV Industri Perbankan.

\begin{tabular}{cccc}
\hline Tahun & Rata-rata harga saham (Rupiah) & $\begin{array}{c}\text { Return On Asset } \\
(\%)\end{array}$ & Price to Book Value (kali) \\
\hline 2013 & 3.082 & 2,39 & 1,67 \\
2014 & 4.241 & 1,89 & 1,69 \\
2015 & 2.813 & 1,81 & 1,53 \\
2016 & 3.476 & 1,70 & 1,93 \\
2017 & 5.010 & 1,86 & 2,02 \\
\hline
\end{tabular}

Sumber : www.idx.co.id (data diolah)

Berdasarkan tabel 1 dapat disimpulkan bahwa nilai rata-rata harga saham cenderung mengalami kenaikan dari Rp. 3.082 ditahun 2013 menjadi Rp. 5.010 ditahun 2017. Sedangkan untuk rata-rata ROA cenderung terus mengalami penurunan dari tahun 2013 sebesar 2,39\% menjadi 1,86\% ditahun 2017. Dan untuk rata-rata nilai PBV cenderung terus mengalami kenaikan ditahun 2013 sebesar 1,67 menjadi 2,02 pada tahun 2017. Dengan demikian dapat disimpulkan bahwa kenaikan antara rata-rata harga saham dan $P B V$ tidak searah dengan nilai $R O A$ yang cenderung terus mengalami penurunan. Sedangkan menurut Harjito dan Martono (2005 : 23) dijelaskan bahwa jika tingkat laba meningkat maka nilai perusahaannya pun akan meningkat. Namun pada data tabel 1 berbeda dan tidak sesuai dengan teori tersebut.

Berdasarkan fenomena tersebut memungkinkan terdapat beberapa faktor lain yang dapat mempengaruhi nilai perusahaan, salah satunya yaitu Adanya kegiatan corporate social responsibility (CSR) yang dilakukan oleh perusahaan. Menurut Mc Williams and Siegel (2001) Saat ini kondisi keuangan saja tidak cukup untuk menjamin suatu perusahaan dapat tumbuh secara berkelanjutan (sustainable). Keberlanjutan suatu perusahaan hanya akan dijamin jika perusahaan juga memperhatikan aspek ekonomi, sosial dan lingkungan. Faktor kedua yang memungkinkan dapat mempengaruhi nilai perusahaan yaitu dilihat dari kemampuan perusahaan dalam membayarkan dividennya, karena jumlah dividen yang dibayarkan dapat mempengaruhi harga saham perusahaan. Dalam penelitian ini profitabilitas yang diukur dengan return on assets dijadikan sebagai variabel pemoderasi. hal tersebut diharapkan dapat memperkuat hubungan antara pengaruh CSR dan kebijakan dividen terhadap nilai perusahaan.

Berdasarkan pada fenomena yang terjadi maka peneliti tertarik untuk melakukan penelitian dengan judul "Analisis Pengaruh Corporate Social Responsibility dan Kebijakan Dividen Terhadap Nilai Perusahaan dengan Profitabilitas sebagai Variabel Pemoderasi (Studi pada Industri Perbankan yang Terdaftar di Bursa Efek Indonesia periode 2013 - 2017)". 


\section{HIPOTESIS PENELITIAN}

H1 : Corporate social responsibility berpengaruh positif terhadap nilai perusahaan

H2 : Kebijakan dividen berpengaruh positif terhadap nilai perusahaan

H3 : Profitabilitas mampu memoderasi pengaruh corporate social responsibility terhadap nilai perusahaan

H4 : Profitabilitas mampu memoderasi pengaruh kebijakan dividen terhadap nilai perusahaan

\section{METODE PENELITIAN}

\section{Jenis Penelitian}

Jenis penelitian dalam penelitian ini adalah penelitian kuantitatif yang berbentuk asosiatif karena penelitian ini menggunakan data yang berupa angka dan bertujuan untuk menganalisis hubungan atau pengaruh antara dua variabel atau lebih (Suliyanto, 2018:15)

\section{Populasi dan Sampel Penelitian}

Populasi dalam penelitian ini adalah industri perbankan yang terdaftar di Bursa Efek Indonesia periode tahun 2013-2017 yaitu sebanyak 43 bank. Sampel yang diambil dari populasi dalam penelitian ini didasarkan pada beberapa kriteria, yaitu: a) Perbankan yang terdaftar di Bursa Efek Indonesia selama periode 2013 - 2017, b) Perbankan yang memiliki laporan keuangan lengkap selama periode 2013 - 2017, c) Perbankan yang menyediakan informasi mengenai CSR secara berturut - turut selama periode 2013 - 2017. d) Perbankan yang membagikan dividen secara berturut - turut selama periode $2013-2017$.

\section{Jenis dan Sumber Data}

Jenis data yang digunakan dalam penelitian ini adalah data sekunder. Data sekunder dalam penelitian ini diperoleh dari laporan tahunan (annual report) dan laporan keberlanjutan (sustainability report) industri perbankan periode tahun 2013 - 2017 yang dapat diakses melalui situs www.idx.co.id dan website dari masing-masing perusahaan.

\section{Teknik Pengumpulan Data}

Metode yang digunakan dalam penelitian ini adalah Dokumentasi dan menggunakan metode studi pustaka.

\section{TEKNIK ANALISIS DATA}

\section{Analisis Statistik Deskriptif}

Statistik deskriptif adalah statistik yang digunakan untuk menganalisa data dengan cara mendeskripsikan atau menggambarkan data yang telah terkumpul sebagaimana adanya tanpa bermaksud membuat kesimpulan yang berlaku untuk umum atau generalisasi (Sugiyono, 2012 : 206).

\section{Metode Pemilihan Model Regresi Data Panel}

\section{Common Effect Model}

Metode common effect merupakan metode yang paling sederhana karena hanya menggabungkan data time series dengan cross section tanpa memperhatikan dimensi waktu maupun individu. Metode ini dapat menggunakan pendekatan Ordinary Least Square (OLS) atau teknik kuadrat terkecil untuk mengestimasi model data panel.

\section{Model Pendekatan Efek Tetap (Fixed Effect Model)}

Fixed effect model mengasumsikan bahwa intersep dari setiap individu adalah berbeda sedangkan slope antar individu tetap atau sama. Perbedaan intersep bisa terjadi karena perbedaan budaya kerja, manajerial dan intensif. Teknik ini menggunakan variabel dummy untuk menangkap adanya perbedaan intersep antar individu.

\section{Model Pendekatan Efek Acak (Random Effect Model)}

Model ini mengasumsikan bahwa setiap perusahaan mempunyai perbedaan intersep yang mana intersep tersebut adalah variabel random. Metode analisis data panel dengan meggunakan model random effect harus memenuhi persyaratan yaitu jumlah cross section harus lebih besar daripada jumlah variabel penelitian. 
Pada dasarnya ketiga teknik estimasi data panel dapat dipilih sesuai dengan keadaan penelitian salah satunya dapat dilihat dari variabel penelitiannya. Namun ada beberapa cara yang dapat digunakan untuk menentukan teknik mana yang paling tepat dalam mengestimasi data panel.

Menurut Widarjono (2007:258) terdapat tiga uji untuk memilih teknik estimasi data panel yaitu :

Uji Chow

Uji ini dilakukan untuk mengetahui apakah teknik regresi data panel dengan fixed effect model lebih baik dari regresi model data panel tanpa variabel dummy atau common effect model. Jika nilai probabilitas chi square $<\alpha=0,05$ maka $\mathrm{H}_{0}$ ditolak artinya model yang tepat untuk regresi data panel adalah fixed effect model begitu pula sebaliknya.

\section{Uji Hausman}

Uji ini merupakan pengujian statistik yang digunakan untuk memilih apakah menggunakan fixed effect model atau random effect model. Jika nilai probabilitas cross section random $<\alpha=0,05$ maka $\mathrm{H}_{0}$ ditolak yang artinya model yang tepat untuk data panel adalah fixed effect model begitu pula sebaliknya.

\section{Uji Lagrange Multiplier (LM)}

Digunakan untuk memilih apakah random effect model lebih baik dari common effect model. Apabila nilai LM hitung lebih besar dari nilai kritis Chi Square maka $\mathrm{H}_{0}$ ditolak artinya model yang tepat untuk regresi data panel adalah random effect model begitu pula sebaliknya.

\section{Uji Asumsi Klasik}

\section{Uji Normalitas}

Dalam penelitian ini menggunakan metode Jarque Bera. keputusan apakah residual terdistribusi normal atau tidak dengan cara membandingkan nilai probabilitas jarque bera dengan tingkat alpha $(0,05)$.

\section{Uji Multikolinieritas}

Uji multikolinieritas dalam penelitian ini dilakukan dengan cara menganalisis correlation matrix pada masing - masing variabel independennya. Apabila antar variabel terdapat korelasi yang tinggi yaitu diatas 0,8 maka dapat disimpulkan bahwa terdapat masalah multikolinieritas (Winarno, 2009).

\section{Uji Heteroskedastisitas}

Dalam penelitian ini menggunakan uji heteroskedastisitas dengan metode Park. Jika terdapat variabel bebas yang signifikan atau nilai probabilitasnya lebih dari alpha $(0,05)$ terhadap nilai Ln residual kuadrat $\left(\operatorname{Ln~}^{2}\right)$ maka dalam model terdapat masalah heteroskedastisitas (Suliyanto, 2011 : 102).

\section{Uji Otokorelasi}

Uji otokorelasi dimaksudkan untuk mengetahui apakah ada korelasi antara anggota serangkaian data observasi yang diuraikan menurut waktu (time-series) atau ruang (cross section) (Suliyanto, 2011 : 125). Dalam penelitian ini menggunakan uji Otokorelasi dengan metode Durbin-Watson

\section{Analisis Regresi Data Panel}

Model persamaan regresi yang diguanakan adalah sebagai berikut :

\section{Analisis Regresi Moderasi}

$$
Y=\propto+\beta_{1} X_{1}+\beta_{2} X_{2}+e
$$

Model persamaan regresi moderasi dalam penelitian ini adalah sebagai berikut:

\section{Uji Koefisien Determinasi ( $\left.R^{2}\right)$}

$$
Y=\alpha+\beta_{1} X_{1}+\beta_{2} X_{2}+\beta_{3} X_{1} Z+\beta_{4} X_{2} Z+e
$$

Koefisien determinasi pada intinya menunjukkan besarnya kontribusi variabel independen terhadap variabel dependen. Semakin tinggi koefisien determinasi, maka semakin tinggi kemampuan variabel independen dalam menjelaskan variasi perubahan pada variabel dependen (Suliyanto, 2011: $55)$.

\section{Uji F Hitung}

Nilai F hitung bertujuan untuk menguji ketepatan model (goodness of fit), apakah model persamaan yang terbentuk dalam kriteria cocok (fit) atau tidak. Uji $\mathrm{F}$ ini juga disebut dengan uji simultan, yakni untuk menguji apakah variabel bebas mampu menjelaskan perubahan nilai variabel tergantung atau tidak Suliyanto (2011:44). 
Uji t

Suatu variabel akan memiliki pengaruh yang berarti jika nilai t hitung variabel lebih besar daripada nilai $\mathrm{t}$ tabel. Penelitian ini menggunakan uji $\mathrm{t}$ satu ujung (one tailed) dengan $\alpha=0,05 \mathrm{dan} \mathrm{df}=$ $\mathrm{n}-\mathrm{k}$.

Kriteria pengujian hipotesis yaitu sebagai berikut : a) Ho diterima dan Ha ditolak jika thitung $\leq$ tabel atau sig. $>0,05$, b) Ha diterima dan Ho ditolak jika thitung > tabel atau sig. $\leq 0,05$

Kriteria pengujian untuk hipotesis moderasi yaitu sebagai berikut : a) Ho diterima dan Ha ditolak jika sig. $>0,05$, b) Ha diterima dan Ho ditolak jika sig. $\leq 0,05$.

\section{HASIL DAN PEMBAHASAN}

Analisis Data

Analisis Statistik Deskriptif

Berikut ini adalah hasil dari analisis statistik deskriptif perusahaan sampel secara keseluruhan. Tabel 2. Hasil Analisis Statistik Deskriptif

\begin{tabular}{|c|c|c|c|c|c|}
\hline \multicolumn{6}{|c|}{ Descriptive Statistics } \\
\hline Variables & $\mathrm{N}$ & Min. & Max. & Mean & Std. Deviation \\
\hline PBV & 60 & 0,03 & 4,27 & 1,7459 & 1,01502 \\
\hline CSR & 60 & 0,04 & 0,70 & 0,2542 & 0,18667 \\
\hline DPR & 60 & 0,09 & 0,90 & 0,3369 & 0,20275 \\
\hline ROA & 60 & 0,01 & 0,04 & 0,0190 & 0,00806 \\
\hline
\end{tabular}

Penentuan Model Analisis

Analisis regresi data panel dapat dilakukan dengan tiga model yaitu common effect model, fixed effect model dan random effect model. Langkah pertama yang harus dilakukan adalah memilih model terbaik dari tiga model tersebut, dengan cara meregresikan data panel yang telah dikumpulkan dengan metode common effect model dan fixed effect model yang hasilnya dapat dilihat pada tabel 3 dan tabel 4 .

Dependent Variable: PBV

Tabel 3. Hasil Uji Common Effect Model

Method: Panel Least Squares

Date: 08/22/19 Time: 22:09

Sample: 20132017

Periods included: 5

Cross-sections included: 12

Total panel (balanced) observations: 60

\begin{tabular}{ccccc}
\hline \hline Variable & Coefficient & Std. Error & t-Statistic & Prob. \\
\hline C & 1.560438 & 0.288692 & 5.405208 & 0.0000 \\
CSR & 1.338568 & 0.709581 & 1.886420 & 0.0643 \\
DPR & -0.459627 & 0.653299 & -0.703548 & 0.4846 \\
\hline \hline R-squared & 0.060878 & Mean dependent var & 1.745886 \\
Adjusted R-squared & 0.027927 & S.D. dependent var & 1.015016 \\
S.E. of regression & 1.000743 & Akaike info criterion & 2.888069 \\
Sum squared resid & 57.08471 & Schwarz criterion & 2.992786 \\
Log likelihood & -83.64206 & Hannan-Quinn criter. & 2.929029 \\
F-statistic & 1.847508 & Durbin-Watson stat & 0.579918 \\
Prob(F-statistic) & 0.166944 & & \\
\hline \hline
\end{tabular}


Dependent Variable: PBV

Tabel 4. Hasil Uji Fixed Effect Model

Method: Panel Least Squares

Date: 08/22/19 Time: 22:07

Sample: 20132017

Periods included: 5

Cross-sections included: 12

Total panel (balanced) observations: 60

\begin{tabular}{|c|c|c|c|c|}
\hline Variable & Coefficient & Std. Error & t-Statistic & Prob. \\
\hline $\mathrm{C}$ & 1.371602 & 0.242610 & 5.653537 & 0.0000 \\
\hline CSR & -0.408926 & 0.515788 & -0.792819 & 0.4320 \\
\hline DPR & 1.419670 & 0.620160 & 2.289199 & 0.0267 \\
\hline \multicolumn{5}{|c|}{ Effects Specification } \\
\hline \multicolumn{5}{|c|}{ Cross-section fixed (dummy variables) } \\
\hline R-squared & 0.759727 & \multicolumn{2}{|c|}{ Mean dependent var } & 1.745886 \\
\hline Adjusted R-squared & 0.691824 & \multicolumn{2}{|c|}{ S.D. dependent var } & 1.015016 \\
\hline S.E.of regression & 0.563472 & \multicolumn{2}{|c|}{ Akaike info criterion } & 1.891566 \\
\hline Sum squared resid & 14.60504 & \multicolumn{2}{|c|}{ Schwarz criterion } & 2.380247 \\
\hline Log likelihood & -42.74698 & \multicolumn{2}{|c|}{ Hannan-Quinn criter. } & 2.082716 \\
\hline F-statistic & 11.18838 & \multicolumn{2}{|c|}{ Durbin-Watson stat } & 2.209451 \\
\hline Prob(F-statistic) & 0.000000 & & & \\
\hline
\end{tabular}

Langkah selanjutnya yaitu memilih antara model yang tepat antara common effect model dan fixed effext model dengan menggunakan uji chow. Hasil analisis uji chow dapat dilihat pada tabel 5 sebagai berikut:

Tabel 5. Hasil Uji Chow

Redundant Fixed Effects Tests

Equation: Untitled

Test cross-section fixed effects

\begin{tabular}{cccc}
\hline \hline Effects Test & Statistic & d.f. & Prob. \\
\hline \hline Cross-section F & 12.163073 & $(11,46)$ & 0.0000 \\
Cross-section Chi-square & 81.790155 & 11 & 0.0000 \\
\hline \hline
\end{tabular}

Berdasarkan hasil uji chow menunjukkan bahwa probabilitas chi square adalah 0,0000<0,05. Dengan demikian model yang tepat pada uji chow adalah fixed effect model. Langkah selanjutnya adalah memilih model yang tepat antara fixed effect model dengan random effect model. Hasilnya dapat dilihat pada tabel 6 sebagai berikut:

Tabel 6. Hasil Uji Random Effect Model

Dependent Variable: PBV

Method: Panel EGLS (Cross-section random effects)

Date: 08/22/19 Time: 22:10

Sample: 20132017

Periods included: 5

Cross-sections included: 12

Total panel (balanced) observations: 60

Swamy and Arora estimator of component variances

\begin{tabular}{ccccc}
\hline \hline Variable & Coefficient & Std. Error & t-Statistic & Prob. \\
\hline \hline C & 1.444481 & 0.319233 & 4.524849 & 0.0000 \\
CSR & -0.149557 & 0.500153 & -0.299021 & 0.7660
\end{tabular}




\begin{tabular}{|c|c|c|c|c|}
\hline DPR & 1.007595 & 0.571644 & 1.762626 & 0.0833 \\
\hline \multicolumn{5}{|c|}{ Effects Specification } \\
\hline & & & S.D. & Rho \\
\hline Cross-section random & & & 0.776682 & 0.6552 \\
\hline Idiosyncratic random & & & 0.563472 & 0.3448 \\
\hline \multicolumn{5}{|c|}{ Weighted Statistics } \\
\hline R-squared & 0.047975 & Mean & קendent var & 0.538799 \\
\hline Adjusted R-squared & 0.014571 & S.D. & endent var & 0.590584 \\
\hline S.E. of regression & 0.586266 & Sum & lared resid & 19.59134 \\
\hline F-statistic & 1.436190 & Durb & Natson stat & 1.573095 \\
\hline Prob(F-statistic) & 0.246307 & & & \\
\hline \multicolumn{5}{|c|}{ Unweighted Statistics } \\
\hline R-squared & -0.070986 & Mean & Jendent var & 1.745886 \\
\hline Sum squared resid & 65.10008 & Durb & Natson stat & 0.473410 \\
\hline
\end{tabular}

Setelah dilakukan analisis random effect model maka langkah selanjutnya adalah memilih model yang tepat antara fixed effect model dengan random effect model menggunakan uji hausman. Hasilnya dapat dilihat pada tabel 7 sebagai berikut:

Tabel 7. Hasil Analisis Uji Hausman

Correlated Random Effects - Hausman Test

Equation: Untitled

Test cross-section random effects

\begin{tabular}{|c|c|c|c|c|}
\hline Test Summary & & Chi-Sq. Statistic & Chi-Sq. d.f. & Prob. \\
\hline Cross-section random & & 6.704822 & 2 & 0.0350 \\
\hline \multicolumn{5}{|c|}{ Cross-section random effects test comparisons: } \\
\hline Variable & Fixed & Random & Var(Diff.) & Prob. \\
\hline CSR & "-0.408926 & -0.149557 & 0.015884 & 0.0396 \\
\hline DPR & 1.419670 & 1.007595 & 0.057821 & 0.0866 \\
\hline
\end{tabular}

Cross-section random effects test equation:

Dependent Variable: PBV

Method: Panel Least Squares

Date: 08/22/19 Time: 23:27

Sample: 20132017

Periods included: 5

Cross-sections included: 12

Total panel (balanced) observations: 60

\begin{tabular}{ccccc}
\hline \hline Variable & Coefficient & Std. Error & t-Statistic & Prob. \\
\hline \hline C & 1.371602 & 0.242610 & 5.653537 & 0.0000 \\
CSR & -0.408926 & 0.515788 & -0.792819 & 0.4320 \\
DPR & 1.419670 & 0.620160 & 2.289199 & 0.0267 \\
\hline \hline \multicolumn{5}{c}{ Effects Specification } \\
\hline \hline Cross-section fixed (dummy variables) & & & \\
\hline \hline R-squared & 0.759727 & Mean dependent var & 1.745886 \\
Adjusted R-squared & 0.691824 & S.D. dependent var & 1.015016 \\
S.E. of regression & 0.563472 & Akaike info criterion & 1.891566 \\
Sum squared resid & 14.60504 & Schwarz criterion & 2.380247 \\
Log likelihood & -42.74698 & Hannan-Quinn criter. & 2.082716 \\
F-statistic & 11.18838 & Durbin-Watson stat & 2.209451 \\
Prob(F-statistic) & 0.000000 & & \\
\hline \hline
\end{tabular}


Berdasarkan uji hausman dapat dilihat bahwa probabilitas cross section random sebesar 0,035< 0,05. Oleh karena itu, model yang dipilih adalah fixed effect model.

Berdasarkan pengujian tersebut, fixed effect model telah terpilih sebanyak 2 kali yaitu pada uji chow dan uji hausman. Sehingga dalam penelitian ini uji lagrange multiplier tidak diperlukan. Dengan demikian dapat disimpulkan bahwa dari ketiga model (common effect model, fixed effect model dan random effect model) dalam penelitian ini fixed effect model lebih baik dalam menginterpretasi regresi data panel.

\section{Uji Asumsi Klasik}

Uji Normalitas

Berikut adalah hasil uji normalitas dengan metode jarque bera test dengan menggunakan software eviews 9 for windows, sebagai berikut:

Tabel 8. Hasil Uji Normalitas dengan Metode Jarque Bera

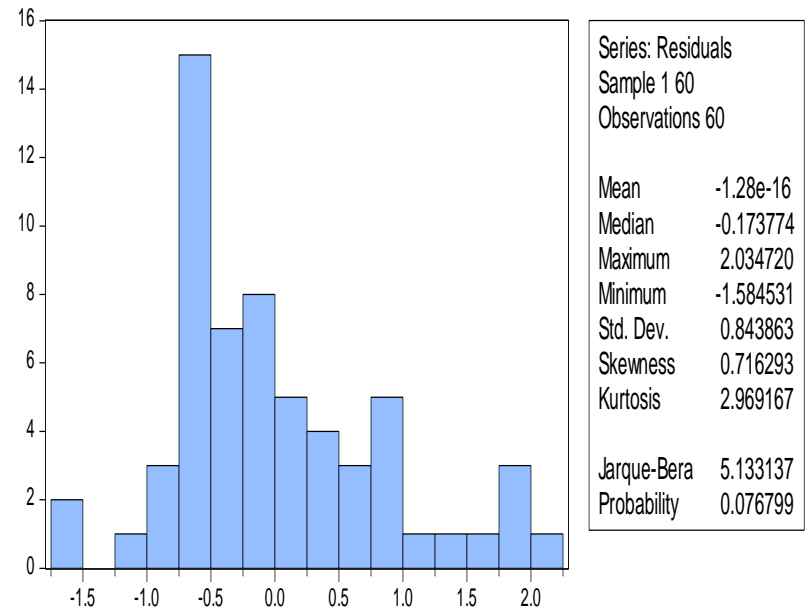

Berdasarkan tabel 8 dapat diketahui bahwa nilai probabilitas sebesar 0,076799>0,05 sehingga dapat disimpulkan bahwa data yang digunakan berdistribusi normal.

Uji Multikolinieritas

Berikut adalah hasil correlation matrix dengan menggunakan software eviews 9 for windows, sebagai berikut:

Tabel 9. Hasil Uji Multikolinieritas Metode Correlation Matrix

\begin{tabular}{cccc}
\hline & CSR & DPR & ROA \\
\hline CSR & 1 & 0.1803580878791708 & 0.24182131603621 \\
DPR & 0.180358087879170 & 1 & -0.07295953130704 \\
ROA & 0.24182131603621 & -0.072959531307042 & 1 \\
\hline
\end{tabular}

Dalam dilihat pada tabel 9 bahwa nilai korelasi pada masing-masing variabel $<0,8$. Sehingga dapat disimpulkan bahwa dalam model regresi tidak terdapat gejala multikoloinieritas.

\section{Uji Heteroskedastisitas}

Uji heteroskedastisitas dalam penelitian ini dilakukan dengan metode park. Apabila hasil dari uji park lebih dari 0,05 maka dapat dinyatakan bahwa model tersebut tidak terdapat adanya heteroskedastisitas. Berikut adalah hasil uji park dengan menggunakan software eviews 9 for windows, sebagai berikut :

Tabel 10. Hasil Uji Heteroskedastisitas dengan Metode Park

Dependent Variable: RESABS

Method: Panel Least Squares

Date: 08/24/19 Time: 19:04

Sample: 20132017

Periods included: 5

Cross-sections included: 12

Total panel (balanced) observations: 60 


\begin{tabular}{|c|c|c|c|c|}
\hline Variable & Coefficient & Std. Error & t-Statistic & Prob. \\
\hline $\mathrm{C}$ & 0.369151 & 0.233231 & 1.582774 & 0.1205 \\
\hline CSR & -0.081855 & 0.269289 & -0.303966 & 0.7626 \\
\hline DPR & 0.092452 & 0.332889 & 0.277727 & 0.7825 \\
\hline ROA & -2.203653 & 9.160997 & -0.240547 & 0.8110 \\
\hline \multicolumn{5}{|c|}{ Effects Specification } \\
\hline \multicolumn{5}{|c|}{ Cross-section fixed (dummy variables) } \\
\hline R-squared & 0.451770 & \multicolumn{2}{|c|}{ Mean dependent var } & 0.337696 \\
\hline $\begin{array}{l}\text { Adjusted R- } \\
\text { squared }\end{array}$ & 0.281209 & \multicolumn{2}{|c|}{ S.D. dependent var } & 0.346112 \\
\hline $\begin{array}{l}\text { S.E. of regression } \\
\text { Sum squared }\end{array}$ & 0.293439 & \multicolumn{2}{|c|}{ Akaike info criterion } & 0.598026 \\
\hline resid & 3.874798 & \multicolumn{2}{|c|}{ Schwarz criterion } & 1.121612 \\
\hline Log likelihood & -2.940783 & \multirow{2}{*}{\multicolumn{2}{|c|}{$\begin{array}{l}\text { Hannan-Quinn criter. } \\
\text { Durbin-Watson stat }\end{array}$}} & 0.802829 \\
\hline F-statistic & 2.648734 & & & 2.504969 \\
\hline Prob(F-statistic) & 0.006764 & & & \\
\hline
\end{tabular}

Dapat dilihat pada tabel 10 bahwa dalam penelitian ini tidak terdapat gejala heteroskedastisitas karena masing - masing probabilitasnya $>0,05$.

\section{Uji Otokorelasi}

Dalam penelitian ini menggunakan metode Durbin Watson. Setelah nilai Durbin Watson diketahui selanjutnya dibandingkan dengan nilai pada tabel Durbin Watson dengan ketentuan $\mathrm{n}=60, \mathrm{k}=3, \alpha=$ 0,05 dan agar tidak terjadi masalah otokolerasi maka nilai $\mathrm{dU}<$ nilai Durbin Warson $<4-\mathrm{dU}$. Berikut adalah hasil uji otokorelasi dengan menggunakan metode Durbin Watson.

Tabel 11. Hasil Uji Otokorelasi dengan Metode Durbin Watson

Breusch-Godfrey Serial Correlation LM Test:

\begin{tabular}{lccc}
\hline \hline F-statistic & 4.104731 & Prob. F(4,52) & 0.0058 \\
Obs*R-squared & 14.39858 & Prob. Chi-Square(4) & 0.0061 \\
\hline \hline
\end{tabular}

Test Equation:

Dependent Variable: RESID

Method: Least Squares

Date: 09/20/19 Time: 18:37

Sample: 160

Included observations: 60

Presample missing value lagged residuals set to zero.

\begin{tabular}{ccccc}
\hline \hline Variable & Coefficient & Std. Error & t-Statistic & Prob. \\
\hline \hline C & 0.408231 & 0.332052 & 1.229419 & 0.2244 \\
CSR & -0.450710 & 0.609599 & -0.739355 & 0.4630 \\
DPR & 0.197177 & 0.517115 & 0.381303 & 0.7045 \\
ROA & -19.38274 & 14.13220 & -1.371530 & 0.1761 \\
RESID(-1) & 0.434697 & 0.137805 & 3.154429 & 0.0027 \\
RESID(-2) & 0.087589 & 0.160766 & 0.544825 & 0.5882 \\
RESID(-3) & 0.185230 & 0.148064 & 1.251013 & 0.2165 \\
RESID(-4) & -0.028238 & 0.139048 & -0.203079 & 0.8399 \\
\hline \hline R-squared & 0.239976 & \multicolumn{2}{c}{ Mean dependent var } & $-3.09 \mathrm{E}-16$ \\
Adjusted R-squared & 0.137665 & S.D. dependent var & 0.814647 \\
S.E. of regression & 0.756497 & \multicolumn{2}{c}{ Akaike info criterion } & 2.403331 \\
Sum squared resid & 29.75900 & \multicolumn{2}{c}{ Schwarz criterion } & 2.682577 \\
Log likelihood & -64.09992 & \multicolumn{2}{c}{ Hannan-Quinn criter. } & 2.512559 \\
F-statistic & 2.345561 & \multicolumn{2}{c}{ Durbin-Watson stat } & 1.836618
\end{tabular}


Prob(F-statistic)

0.036907

Berdasarkan pada tabel 11 dapat diketahui bahwa nilai Durbin Watson $(1,836618)$ dengan dU $(1,6889)$ dan 4 - dU $(2,5203)$ maka dapat disimpulkan bahwa model regresi tidak terjadi masalah otokorelasi karena nilai Durbin Watson berada antara dU dan 4 - dU yaitu 1,6889<1,836618< 2,3111 .

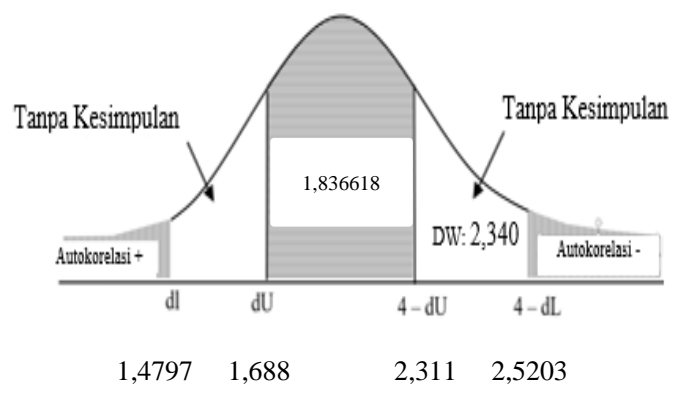

\section{Analisis Hasil Regresi Data Panel}

Gambar 1. Kurva Hasil Uji Otokorelasi Durbin - Watson

Setelah dilakukannya pemilihan model, model yang tepat dalam penelitian ini adalah fixed effect model.

Berdasarkan output pada tabel 4, maka dapat disusun persamaan sebagai berikut:

$$
\mathrm{PBV}=1,371602-0,408926 \mathrm{CSR}+1,419670 \mathrm{DPR}+e
$$

\section{Analisis Hasil Uji Regresi Moderasi}

Dalam analisis regresi moderasi ini menggunakan metode interaksi dengan bantuan program eviews 9 for windows. Hasil analisis regresi moderasi adalah sebagai berikut:

Dependent Variable: PBV

Tabel 12. Hasil Uji Regresi Moderasi I

Method: Panel Least Squares

Date: 08/24/19 Time: 18:37

Sample: 20132017

Periods included: 5

Cross-sections included: 12

Total panel (balanced) observations: 60

\begin{tabular}{ccccc}
\hline \hline Variable & Coefficient & Std. Error & t-Statistic & Prob. \\
\hline \hline C & 0.431631 & 0.450213 & 0.958725 & 0.3418 \\
CSR & -0.225329 & 1.609864 & -0.139968 & 0.8892 \\
ROA & 62.82440 & 22.38510 & 2.806528 & 0.0069 \\
CSR*ROA & 34.77801 & 71.32120 & 0.487625 & 0.6277 \\
\hline \hline R-squared & 0.358024 & Mean dependent var & 1.745886 \\
Adjusted R- & 0.323632 & S.D. dependent var & 1.015016 \\
squared & 0.834765 & Akaike info criterion & 2.541008 \\
S.E. of regression & Schwarz criterion & 2.680631 \\
Sum squared resid & 39.02265 & Hannan-Quinn criter. & 2.595622 \\
Log likelihood & -72.23024 & Durbin-Watson stat & 0.907033 \\
F-statistic & 10.41022 & & \\
Prob(F-statistic) & 0.000015 & &
\end{tabular}

Tabel 13. Hasil Analisis Uji Regresi Moderasi II

Dependent Variable: PBV

Method: Panel Least Squares

Date: 08/24/19 Time: 18:45 
Sample: 20132017

Periods included: 5

Cross-sections included: 12

Total panel (balanced) observations: 60

\begin{tabular}{ccccc}
\hline \hline Variable & Coefficient & Std. Error & t-Statistic & Prob. \\
\hline \hline C & -1.363645 & 0.378616 & -3.601660 & 0.0007 \\
DPR & 6.307188 & 1.087187 & 5.801384 & 0.0000 \\
ROA & 178.8054 & 19.61795 & 9.114377 & 0.0000 \\
ROA*DPR & -383.6718 & 60.92104 & -6.297854 & 0.0000 \\
\hline \hline R-squared & 0.617892 & \multicolumn{2}{c}{ Mean dependent var } & 1.745886 \\
Adjusted R-squared & 0.597422 & S.D. dependent var & 1.015016 \\
S.E. of regression & 0.644018 & Akaike info criterion & 2.022161 \\
Sum squared resid & 23.22654 & \multicolumn{2}{c}{ Schwarz criterion } & 2.161784 \\
Log likelihood & -56.66484 & \multicolumn{2}{c}{ Hannan-Quinn criter. } & 2.076776 \\
F-statistic & 30.18510 & \multicolumn{2}{c}{ Durbin-Watson stat } & 1.836054 \\
Prob(F-statistic) & 0.000000 & & \\
\hline \hline
\end{tabular}

Persamaan regresi yang terbentuk dari hasil analisis uji regresi moderasi pada tabel 12 dan tabel 13 adalah sebagai berikut:

$\mathrm{PBV}=0,431631-0,225329 \mathrm{CSR}+62,82440 \mathrm{ROA}+34,77801 \mathrm{CSR} \cdot \mathrm{DPR}+e$

$\mathrm{PBV}=-1,363645+6,307188 \mathrm{DPR}+178,8054 \mathrm{ROA}-383,6718 \mathrm{DPR} \cdot \mathrm{ROA}+e$

Uji Goodness of Fit (Uji F)

Berdasarkan hasil analisis pada tabel 4 dapat diketahui bahwa nilai $\mathrm{F}$ hitung adalah sebesar 11,18838 dan nilai $\mathrm{F}$ tabelnya adalah 4,01 yang berarti bahwa $\mathrm{F}$ hitung $>\mathrm{F}$ tabel sedangkan nilai signifikansinya adalah sebesar $0,0000<\alpha 0,05$. Berdasarkan penjelasan tersebut dapat dikatakan bahwa model yang terbentuk cocok atau fit. Sehingga variabel corporate social responsibility dan kebijakan dividen berpengaruh secara simultan terhadap nilai perusahaan.

Sementara itu untuk hasil analisis moderasi I pada tabel 12 dapat diketahui bahwa nilai $\mathrm{F}$ hitung sebesar 10,41022 dan nilai $\mathrm{F}$ tabelnya adalah sebesar 3,16 yang berarti bahwa $\mathrm{F}$ hitung $>\mathrm{F}$ tabel dan nilai signifikansinya adalah sebesar $0,000>0,05$. Berdasarkan penjelasan tersebut dapat dikatakan bahwa model yang terbentuk cocok atau fit.

Berdasarkan hasil analisis pada tabel 13 dapat diketahui bahwa nilai $\mathrm{F}$ hitung adalah sebesar 30,18510 dan nilai $\mathrm{F}$ tabelnya adalah 3,16 yang berarti bahwa nilai $\mathrm{F}$ hitung $>\mathrm{F}$ tabel dan nilai signifikansinya adalah $0,000>0,05$. Maka berdasarkan pada penjelasan tersebut model yang terbentuk dapat dikatakan cocok atau fit.

Uji Parsial (Uji t Statistik)

Berikut dibawah ini adalah rangkuman dari hasil analisis uji t sebagai berikut :

Tabel 14. Ringkasan Uji t Statistik

\begin{tabular}{lrrrl}
\hline \multicolumn{1}{r}{ Variabel } & t hitung & t tabel & \multicolumn{1}{c}{ sig } & \multicolumn{1}{c}{ Pengaruh } \\
\hline CSR & $-0,792819$ & 2,00247 & 0,4320 & Tidak berpengaruh \\
DPR & 2,289199 & 2,00247 & 0,0267 & Positif dan signifikan \\
CSR.ROA & 0,487625 & 2,00324 & 0,6277 & Tidak berpengaruh \\
DPR.ROA & $-6,297854$ & $-2,00324$ & 0,000 & Negatif dan signifikan \\
\hline
\end{tabular}

Sumber : Data diolah

Berdasarkan hasil analisis pada tabel 14 dapat diketahui bahwa nilai $\mathrm{F}$ hitung adalah sebesar 30,18510 dan nilai $\mathrm{F}$ tabelnya adalah 3,16 yang berarti bahwa nilai $\mathrm{F}$ hitung $>\mathrm{F}$ tabel dan nilai signifikansinya adalah $0,000>0,05$. Maka berdasarkan pada penjelasan tersebut model yang terbentuk dapat dikatakan cocok atau fit. 


\section{PEMBAHASAN}

\section{Pengaruh corporate social responsibility terhadap nilai perusahaan}

Hasil analisis menunjukkan bahwa Corporate Social Responsibility tidak berpengaruh terhadap nilai perusahaan perbankan, hal ini dibuktikan dengan hasil nilai t hitung $(-0,792819)$ dan tingkat signifikansinya $(0,4320)$. Hal tersebut dikarenakan para investor tidak merespon atas apa yang sudah perusahaan lakukan dengan bentuk kepeduliannya terhadap sosial, ekonomi dan lingkungan. Oleh karena itu, CSR tidak memberikan pengaruh yang signifikan terhadap nilai perusahaan. Perusahaan belum mampu melakukan pengkomunikasian secara tepat sehingga oleh investor belum ditangkap sebagai suatu aspek yang perlu diperhatikan. Pada perusahaan perbankan, CSR tidak berpengaruh terhadap nilai perusahaan dikarenakan perbankan hanya berfokus pada faktor keuangannya saja, hal tersebut dapat dilihat pada masih minimnya perbankan yang memperhatikan faktor-faktor nonkeuangan seperti CSR. Secara teori CSR seharusnya dapat menjadi pertimbangan investor sebelum melakukan investasi namun kecenderungan investor untuk membeli saham guna memperoleh capital gain dan menerima pembayaran dividen dalam waktu singkat tanpa memperhatikan keberlangsungan perusahaan dalam jangka panjang membuat pengungkapan CSR tidak berpengaruh terhadap nilai perusahaan.

\section{Pengaruh kebijakan dividen terhadap nilai perusahaan}

Hasil analisis menunjukkan bahwa Kebijakan dividen berpengaruh terhadap nilai perusahaan, yaitu dengan nilai t hitung $(2,289199)$ dan tingkat signifikasinya $(0,0267)$. Sesuai dengan teori sinyal yang menyatakan bahwa pembagian dividen dapat dijadikan sinyal untuk perusahaan dalam meramalkan penghasilan dimasa yang akan datang. Dividen merupakan tujuan dari setiap dilakukannya investasi, dengan pembagian dividen yang sesuai dengan harapan (tinggi) maka kesejahteraan para investor pun akan terpenuhi. Hal tersebut akan menimbulkan rasa percaya dari para investor untuk tetap menanamkan sahamnya bahkan memungkinkan investor tersebut akan menaikkan nominal investasinya, hal tersebut nantinya akan berdampak pada meningkatnya nilai perusahaan. Hal tersebut juga didukung oleh teori Bird In The Hand yang menyatakan bahwa pemegang saham lebih senang mendapatkan dividen yang lebih tinggi karena lebih memberikan kepastian. Perusahaan dengan tingkat pembagian dividen yang lebih tinggi akan memperoleh apresiasi yang baik dari para investor, sehingga hal tersebut dapat menjadikan harga saham perusahaan semakin tinggi dan nilai perusahaan akan semakin meningkat.

\section{Pengaruh profitabilitas memoderasi pengaruh corporate social responsibility terhadap nilai} perusahaan

Hasil analisis menunjukkan bahwa Profitabilitas tidak mampu memoderasi pengaruh Corporate Social Responsibility terhadap nilai perusahaan, yaitu dengan nilai t hitung $(0,487625)$ dan tingkat signifikansinya $(0,6277)$. dapat diartikan bahwa CSR tidak dapat meningkatkan nilai perusahaan pada saat profitabilitas perusahan tinggi dan sebaliknya CSR tidak dapat menurunkan nilai perusahaan pada saat profitabilitas rendah. Tidak berpengaruhnya profitabilitas didalam hubungan CSR terhadap nilai perusahaan dikarenakan banyaknya perbankan yang masih enggan untuk mengeluarkan dananya secara lebih guna melakukan kegiatan CSR yang lebih luas. Dalam hal ini, sebesar apapun tingkat profitabilitas perusahaan tidak dapat memperkuat pengaruh CSR terhadap nilai perusahaan.

Pengaruh profitabilitas memoderasi pengaruh kebijakan dividen terhadap nilai perusahaan

Hasil analisis menunjukkan bahwa Profitabilitas mampu memoderasi pengaruh kebijakan dividen terhadap nilai perusahaan, yaitu dengan nilai t hitung $(-6,297854)$ dan tingkat signifikansinya $(0,000)$. Dengan demikian dapat dikatakan bahwa perbankan telah berhasil memperoleh profit yang tinggi pada saat menjalankan operasionalnya, sehingga hal tersebut secara tidak langsung dapat meningkatkan kesejahteraan para pemegang saham. Karena dengan tingkat profitabilitas yang tinggi, dalam penelitian ini diukur dengan Return On Assets (ROA) maka tingkat pengembalian atau return atas investasinya pun akan tinggi. Tingkat pengembalian yang diterima oleh para investor tersebut berupa pendapatan dividen. Dengan tingkat ROA yang tinggi maka tingkat pembayaran dividennya pun akan tinggi, sehingga pihak perbankan pun akan memperoleh apresiasi yang baik dari para investornya. Dengan demikian, para investor akan percaya dan tertarik untuk menanamkan sahamnya diperbankan tersebut sehingga dapat berakibat pada harga saham yang terus meningkat dan berimplikasi pada nilai perusahaan yang signifikan. 


\section{SIMPULAN}

Corporate social responsibility yang diukur dengan corporate social responsibility disclosure index (CSRDI) tidak berpengaruh terhadap nilai perusahaan perbankan yang terdaftar di Bursa Efek Indonesia, sehingga hipotesis ditolak. Kebijakan dividen yang diukur dengan dividend payout ratio (DPR) berpengaruh positif dan signifikan terhadap nilai perusahaan perbankan yang terdaftar di Bursa Efek Indonesia, sehingga hipotesis diterima. Profitabilitas yang diukur dengan return on assets (ROA) tidak mampu memoderasi pengaruh corporate social responsibility terhadap nilai perusahaan perbankan yang terdaftar di Bursa Efek Indonesia, sehingga hipotesis ditolak. Profitabilitas yang diukur dengan return on assets (ROA) mampu memoderasi pengaruh kebijakan dividen terhadap nilai perusahaan perbankan yang terdaftar di Bursa Efek Indonesia, sehingga hipotesis diterima.

\section{DAFTAR PUSTAKA}

Branco, Manuel Castelo and Lucia Lima Rodrigues. (2006). Communication of Corporate Responsibility by Portuguese Banks; A Legitimacy Theory Perspective. Corporate Communications: An International Journal. Vol. 11. No. 3, 232-248.

Brigham, Eugene F. dan Joel F Houston. (2006). Dasar - Dasar Manajemen Keuangan. Jakarta : Salemba Empat.

Bawafi, Muh Hosen, dan Adi Prasetyo. (2015). Pengaruh Pengungkapan Corporate Social Responsibility Terhadap Nilai Perusahaan dengan Profitabilitas sebagai Variabel Pemoderasi. Jurnal Reviu Akuntansi dan Keuangan. Vol. 5. No. 1, 721-730.

Darmanto, Ahmad. (2015). Pengaruh Profitabilitas, Leverage, Kebijakan Dividen, Cash Holding, Ukuran Perusahaan dan Corporate Social Responsibility Terhadap Nilai Perusahaan. Skripsi. Universitas Islam Negeri Syarif Hidayatullah. Jakarta.

Darmawan, Septian (2019) Pengaruh Kebijakan Dividen Terhadap Nilai Perusahaan Dengan Profitabilitas Sebagai Variabel Moderating (Studi Empiris Pada Perusahaan Indeks Kompas 100 Yang Terdaftar Di Bursa Efek Indonesia). Bachelors Degree (S1) Thesis, University Of Muhammadiyah Malang.

Fajriana, Ardianti dan Denies Priantinah. (2016). Pengaruh Corporate Social Responsibility, Keputusan Investasi dan Struktur Modal Terhadap Nilai Perusahaan. Jurnal Nominal. Vol. 5. No. 2.

Ghozali, Imam. (2006). Analisis Multivariate dengan Program SPSS. Edisi Ke 4. Badan Penerbit Universitas Diponegoro : Semarang.

Hadi, Nor. (2011). Corporate Social Responsibility. Yogyakarta : Graha Ilmu.

Harjito, D. A., dan Martono. (2010). Manajemen Keuangan. Ekonisia Kampus Fakulas Ekonomi UII. Yogyakarta

Husnan, Suad dan Enny Pudjiastuti. (2006). Dasar-Dasar Manajemen Keuangan. Edisi Kelima. Yogyakarta : UPP STIM YKPN.

Kartini, Dwi. (2013). Corporate Social Responsibility Transformasi Konsep Sustainability Management dan Implementasi di Indonesia. Bandung. PT Refika Aditama.

Kusumadilaga, Rimba. (2010). Pengaruh Corporate Social Responsibility Terhadap Nilai Perusahaan Dengan Profitabilitas Sebagai Variabel Moderating. Skripsi. Universitas Diponegoro

Kusumawati, Eny dan Zulfa Irawati. 2013. Manajemen Keuangan. Surakarta: Universitas Muhammadiyah Surakarta.

Mcwilliams, Abagail and Donald S Siegel. (2001). Corporate Social Responsibility: A Theory Of The Firm Perspective. Academy Of Management Review. Vol. 26. No. 1, 117-127.

Monoarfa, Rio. (2018). The Role Profitability In Mediating The Effect of Dividend Policy and Company Size On Company Value. Business And Management Studies. Vol. 4. No. 2.

Nurdizal M. Rachman, Asep Efendi dan Emir Wicaksana. (2011). Panduan Lengkap Perencanaan CSR. Jakarta : Penebar Swadaya. 
Oktaviani, Ni Kadek Dewi dan Ida Bagus Putra Astika. (2016). Profitabilitas Dan Leverage Sebagai Pemoderasi Pengaruh Kebijakan Dividen Pada Nilai Perusahaan. E-Jurnal Akuntansi Universitas Udayana. Vol. 14. No. 3, 2192-2219.

Prastuti, Ni Kadek Rai dan I Gede Merta Sudiartha. (2016). Pengaruh Struktur Modal, Kebijakan Dividen dan Ukuran Perusahaan Terhadap Nilai Perusahaan Pada Perusahaan Manufaktur. E-Jurnal Manajemen Unud. Vol. 5. No. 3, 1572-1598.

Primady, Ganang Radityo dan Sugeng Wahyudi. (2015). Pengaruh Corporate Social Responsibility Dan Profitabilitas Terhadap Nilai Perusahaan Dengan Kepemilikan Manajerial Sebagai Variabel Pemoderasi. Diponegoro Journal of Management. Vol. 4. No. 3, 2337-3792.

Pristianingrum, Nurfina. (2017). Pengaruh Ukuran, Profitabilitas dan Pengungkapan CSR Terhadap Nilai Perusahaan Manufaktur yang Terdaftar di Bursa Efek Indonesia. Prosiding Seminar Nasional dan Call Paper Ekonomi dan Bisnis. Jember.

Puspaningrum, Yustisia. (2017). Pengaruh Corporate Social Responsibility dan Kepemilikan Manajerial Terhadap Nilai Perusahaan dengan Profitabilitas dan Ukuran Perusahaan sebagai Variabel Moderating. Jurnal Profita Edisi 2.

Rivai, Achmad. (2018). Pengaruh Corporate Social Responsibility dan Kepemilikan Manajerial Terhadap Nilai Perusahaan dengan Profitabilitas Sebagai Variabel Moderating. Skripsi. Politeknik Negeri Samarinda.

Sartono, Agus. (2001). Manajemen Keuangan Teori dan Aplikasi edisi ke 4. Yogyakarta : BPFE.

Sholekah, Febrina Wibawati dan Lintang Venusita. (2014). Pengaruh Kepemilikan Manajerial, Kepemilikan Institusional, Leverage, Firm Size dan Corporate Social Responsibility Terhadap Nilai Perusahaan Pada Perusahaan High Profie yang Terdaftar di Bursa Efek Indonesia Periode Tahun 2008-2012. Jurnal Ilmu Manajemen. Vol. 2. No. 3

Sudana, I Made. (2015). Manajemen Keuangan Perusahaan: Teori \& Praktik. Edisi 2, Erlangga, Jakarta.

Suliyanto. (2011). Ekonometrika Terapan: Teori Dan Aplikasi Dengan SPSS. Yogyakarta: Andi.

Suliyanto. (2018). Metode Penelitian Bisnis. Yogyakarta : Andi.

Sugiyono. (2012). Metode Penelitian Bisnis. Bandung : Alfabeta.

Statistika untuk Penelitian. Bandung : Alfabeta.

Sutrisno. (2000). Manajemen Keuangan Teori, Konsep dan Aplikasi. Yogyakarta : EKONISIA.

Ulfah, Suci Luthfia. (2014). Pengaruh Kebijakan Dividen, Struktur Modal dan Pengungkapan Corporate Social Responsibility Terhadap Nilai Perusahaan. Artikel. Universitas Negeri Padang.

Widarjono, Agus. (2009). Ekonometrika Pengantar dan Aplikasinya,Edisi Ketiga. Ekonesia. Yogyakarta.

Widyaningsih, Dewi. (2018). Kepemilikan Manajerial, Kepemilikan Institusional, Komisaris Independen Serta Komite Audit Pada Nilai Perusahaan Dengan Pengungkapan CSR Sebagai Variabel Moderating dan Firm Size Sebagai Variabel Kontrol. Jurnal Akuntansi Dan Pajak. Vol. 19. No. 1, 2579-3055.

Zarlia, Jessika dan Hasan Salim. (2014). Analisis Pengaruh Corporate Social Responsibility dan Profitabilitas Terhadap Nilai Perusahaan. Jurnal Manajemen. Vol. 11. No. 2, 38-55. 